aggregation, as Mr. Marriott implies, but rather that we are yet unacquainted with the nature of scarlet fever infection and the manner of its conveyance by these dangerous individuals, for return cases occur amongst patients discharged early as well as amongst those detained for a lengthy period; amongst patients having discharges (nasal and aural) and such as have none ; amongst those discharged from acute as well as from convalescent wards. Again, is the evidence absolnte enough to prove that the phenomenon of return cases is entirely a bospital one? How long does a house remain a centre of infection after a patient has been removed to hospital? for I have known other patients admitted into hospital from the same house on the same day and immediately before the previous patient had been discharged.

Return cases are few-from 2 to 5 per cent. of the discharges. Now, if the other 95 to 98 per cent. of the cases notified were not removed to hospital would there have been no other infections from them? This supposition seems to me incredible.

All these are questions which will have to be discussed and determined in the near future, and if $\mathrm{Mr}$. Marriott's letter sets such inquiries on foot he will have done some good, but the "object lesson" he endeavours to demonstrate from the figures be gives is, in my firm belief, fallacious. I am, Sirs, yours faithfully,

Manchester, Dec. 16th, 1900 . A. J. ToN KIN, M.B. R.U.I.

\section{"POISON IN BEER."}

\section{To the Editors of THW LANCET.}

SIRs,-As there will be no opportunity of raising this question in Parliament for some time, will you allow me, on behalf of my fellow-Members and others interested in the Pure Beer movement, to offer a few observations upon the present aspect of affairs from our point of view ?

We have now had an opportunity of questioning members of the Government whose departments are in some way or other supposed to have jurisdiction, and from the answers received it would appear that the duty of conducting an inquiry in to the circumstances connected with the recent epidemic has devolved upon the Local Government Board. Here I may say that we are so far fortunate in having at the head of that department a man of undoubted conrage and one who may be relied upon, once be is satistied of his facts, to do his duty unflinchingly. We cannot help thinking, however, that it would have been more reassuring to the public mind if a strong expert committee, such as the Manchester Brewers' Association organised, had been immediately appointed by Her Majesty's Government, in which case they would no doubt have retained the services of the official analysts to the Home Office, both of whom are now members of the Brewers' Committee. In France such an epidemic as this would be at once investigated by the Council of Hygiene, or in Germany by the Imperial Board of Health.

In this country, wherever the interest of the beer-drinker crops up it is difficult to find under which thimble the pea really is, but to us it is very clear where the actual responsibility lies. When the advocates for a definition of beer withdrew their Bill in 1896 the Chancellor of the Exchequer promised to appoint a committee, which was subsequently instructed to report "whether legislation is required to pre. vent the use of deleterious substances in the manufacture of beer." The majority of this committee (a departmental not a parliamentary committee) reported that "the Treasury are empowered to urohibit the use in the manufacture of beer of any substance or liquor of a noxious or detrimental nature. It is the duty of the chemists employed in the Government Laboratory to keep a vigilant watch in this respect over all beer brewed and sold, and they have ample opportunities for so doing." Yesterday we were told by the Secretary to the Treasury that the power alluded to was conferred upon the Treasury by the Inland Revenue Act, but that "the duty of providing proper securities for the wholesomeness of beer, like other articles of food, is placed by law on the local authorities subject, if necessary, to the Local Government Board or Board of Agriculture," and that therefore "the "Treasury had not exercised this power." A pretty puzzle this. Between the 'Creasury, the Inland Revenue chemists, the local authorities, the Local Grovernment Board, and the Board of Agriculture, where is the beerdrinker?
Although the Inland Revenue authorities know what firms use substitutes they have resolutely declined to give that information to Parliament and the public. On this point the majority of the committee expressed their opinion that it would be "an inquisitorial interference with business of a rather invidious kind" ; but as their report was practically a justification of the use of these substitutes, it is difficalt to see how it would be "invidious" to state who used them. No, Sirs, the Inland Revenue cfficials consider it their duty to see that as much liquor as possible pays duty, and the brewers who do not contine themselves to malt and hops say that the public like the substitutes, although they have not sufficient confidence in their compounds to call them by any other name than " beer."

It is quite likely that the policy pursued by the Inland Revenue may yet have the opposite result to that anticipated. The present scare has already brought about a considerable diminution in the consumption of beer, to the consequent detriment of the revenue. We believe that the more people are satisfied as to the purity of beer, the more generally they will drink it and the more will the revenue be augmented. Therefore, to our minds, every thing points to the desirability of an early enactment defining " beer," and extending to it the same principle that Parliament has already sanctioned with respect to other important articles of diet. If these objects are to be secured it will be necessary, unless the Government are wise enough to take the matter into their own hands, to have a powerful organisation in order to focus the great volume of public feeling which exists throughout the country and of which ample evidence is afforded by the stream of resolutions of public bodies, as well as private correspondents, which pours in upon me every day.

No one who has read the minority report of the committee above referred to can say that this calamity has come upon the Government and the people without warning. We only hope that the sickness and death amongst our fellow. countrymen in the North, sad as it is, will have the result of bringing about a much-needed reform, but this can never be effected until the masses of the people realise and impress unmistakably upon the Government how vitally their interests are concerned with the purity of the national beverage.-I am, Sirs, yours faithfullv.

House of Commons, Dec. 14th, 1900.

CUTHBERT QUILTER.

\section{A GERMAN CRITICISM OF THE PRESENT STATE OF OTOLOGY IN GREAT BRITAIN.}

To the Editors of THE LANCET.

SIRS, - The debt of gratitude which we owe to our English colleagues, who were the first to promote the stady of otology on a sound scientific basis, will always remain in our memory. Toynbee founded the patholngical anatomy of the ear and was the first to build ap those principles which stamped otology as a science. Nevertheless, his countrymen neglected to gather in the fruits of the seed he had sown and so the leadership of scientific progress in otology passed into the hands of other nations.

However, the growth of otological works in England during the last ten years points to the fact that fresh endeavours are being made to recover lost ground. Still, those who make a point of systematically reading the English literature are of ten astonished at the apparently almost complete ignorance of all foreign writings, and I really am unable to account for this remarkable fact. It may perhaps be due to their ignorance of foreign languages, so often noticeable in our English colleagues, which prevents them from making use of foreign literature, or perhaps owing to their exten. sive private practice they have not sufficient suare time to perase the German scientific writings. This fault alone cannot help giving the experienced reader the impression that the work is not up to date. Many otological writings are published by the English press which no German journal would accept because their contents are already out of date, and many therapeutical suggestions are publisbed as nen which every aural surgeon in Germany has long been acquainted with. If our desire to enlighten our English colleagues on this question is to be of any practical value we must above all prove the accuracy of our assertions. In this I limit myself to a few striking examples. Although the question with regard to ligaturing the jugular vein in cases of sinus 